\title{
JIŘí KOTÁSEK STÁLE MEZI NÁMI
}

Je to zvláštní pocit, vědět, že se už nikdy neotevřou dveře a do nich nevstoupí Jiří Kotásek, vždy usměvavý a optimisticky naladěný, inspirátor, moudrý člověk, vynikající odborník, prostě guru našeho týmu. Profesor Jiř̌i Kotásek zemřel po dlouhé těžké nemoci 22. srpna 2006.

Jiří Kotásek patřil ke generaci českých pedagogů, do jejichž životních osudů a profesní dráhy výrazně zasahovaly historické události a vývoj české společnosti ve dvacátém století. Zejména $\mathrm{v}$ jeho druhé polovině, $\mathrm{kdy}$ byla nastartována jeho vědecká kariéra, znamenal pro Jiř́ho Kotáska období zklamání a nespravedlivostí, které přicházely bez ohledu na jeho odborné kvality a zásluhy o rozvoj oboru, v důsledku společenských poměrů $\mathrm{v}$ tehdejším Československu, umocněné studenou válkou a bipolárním rozdělením světa. Pro bytostného humanistu a přesvědčeného Evropana, kterým byl, to přinášelo značné komplikace a omezení, na čas i vyřazení $\mathrm{z}$ vědeckého života a činnosti vysokoškolského pedagoga, která pro něho byla více posláním než profesí. Velká příležitost pro uplatnění Kotáskovy vědecké a pedagogické erudice nastala až v poslední dekádě století, v životním období, které pro jiného by znamenalo spíše loučení s aktivním profesním životem a uživání si poklidného života v seniorském věku. Vratme se však na začátek.

Jiří Kotásek se narodil 2. prosince 1928 v Brně. Zde prožil své dětství a studentská léta. Moravské kořeny nikdy nezapřel a rád se $\mathrm{k}$ nim vracel. Nikdy neopomněl připomenout, že brněnská univerzita byla jeho almou mater, neodmítl pozvání na vědecká setkání organizovaná brněnskými kolegy i v době, kdy jeho pracovní kapacita byla přeplněna mezinárodními aktivitami a reprezentací české pedagogiky v zahraničí. Moravský fundament $\mathrm{v}$ nejlepším smyslu slova pronikal jeho osobností, vyzařující srdečnost a upř́mnost $\mathrm{v}$ mezilidském kontaktu, a posiloval zemitou důkladnost až tvrdošíjnost, s níž argumentoval, hájil názory a přesvědčení v záležitostech odborných.

Ještě v předmnichovské Československé republice se setkal Jiří Kotásek, coby žák, s obecnou a střední školou, kterou později reflektoval jako tradiční, avšak nesporně kvalitní, poznamenanou předválečnou atmosférou, kdy význam pojmu vlast vzbuzoval zvláštní pocity a národní dimenze dominovala vzdělávání. V jedenácti letech se jako jiní příslušníci jeho generace naučil emocionálně i racionálně vnímat národní ohrožení a nenávidět okupaci. Po válce vstup na vysokou školu, po absolvování Státního mužského učitelského ústavu, znamenal pro Jiř́ího Kotáska seznámení s akademickým prostředím, jeho svobodami i náročnými požadavky na intelektuální výkon, zanedlouho i setkání s mocenskými a totalitními strukturami pronikajícími do akademického prostředí. $V$ té době však jej osobně přímo nezasáhly složité poměry. $\mathrm{V}$ průběhu studia je př́liš nevnímal, uvědomil si je až později, v padesátých letech. Po absolvování studia na Pedagogické fakultě Masarykovy univerzity působil nedlouho jako učitel př́rodopisu, zeměpisu a občanské nauky na druhém a třetím stupni školy. $\mathrm{V}$ roce 1950 se vrátil na fakultu jako asistent. $\mathrm{V}$ roce 1953 získal doktorát z pedagogiky a psychologie. Byl přijat do vědecké aspirantury na Vysoké škole pedagogické v Praze, jeho školitelem byl profesor Váňa. V roce 1958 získává kandidaturu věd, když ob- 
hájil kandidátskou disertaci Osvojování prírodovědných zákonů ve vyučovacím procesu. V prvním období vědecké práce se orientoval na didaktiku a publikoval studie z didaktiky př́rodovědných předmětů. Studium sovětských prací, zejména z pedagogické psychologie, a prací německých a polských pedagogů ho přivádí $\mathrm{k}$ metodologickým problémům pedagogiky, zejména k zájmu o empirický výzkum vyučovacího procesu. Začíná se také zajímat o vzdělávací reformy, zejména o švédskou reformu, reflektující model sociálního státu. Zatímco zákon o jednotném školství z roku 1949 považoval za průlomový a přijal jej s optimismem, zideologizovanou a politicky silně oktrojovanou korekci školství, kterou předznamenal zákon z roku 1953, již přijal se značnou dávkou kritičnosti.

Od roku 1961 působil Jiř́ Kotásek v Ústavu pro dálkové studium Univerzity Karlovy, pozdějším Ústavu pro učitelské vzdělávání Pedagogické fakulty UK. Činnosti vysokoškolského pedagoga propojoval s intenzivní činností vědeckou, zájem o teoretické a metodologické problémy převažuje. Kromě toho se Jiří Kotásek podílí na tvorbě vysokoškolských učebnic didaktiky a pedagogiky jako člen autorského kolektivu, zpracovává také kapitoly do učebnice pro učitele učňovských škol a mistry odborného výcviku. $\mathrm{V}$ jedné výzkumné linii se i nadále zabývá didaktickými problémy, nově se otevírá druhá výzkumná linie, zaměřená na vzdělávání a učební procesy v dospělosti. Konceptu celoživotního vzdělávání jako předmětu pedagogické teorie je věnován jeho habilitační spis Př́spěvky k teorii vzdělávání dospělých (1965). Období politického uvolňování mu umožňuje výraznější orientaci na západní pedagogické teorie a zkušenosti. Vykonal v té době několik studijních cest - do Dánska, Rakouska, Velké Británie a Spolkové republiky Německo. Angažuje se v UNESCO jako konzultant a vede tým mezinárodního projektu zabývajícího se otázkami systému a obsahu učitelského vzdělávání, využívajícího mezinárodní komparace. Výsledky předkládá v roce 1967 mezinárodní konferenci expertů. Propojením problémů vysokoškolské didaktiky a vzdělávání dospělých se přiblížil $\mathrm{k}$ otázkám učitelského vzdělávání a jeho systému, které se staly jeho trvalým zájmem a představují také výraznou část titulů jeho osobní bibliografie. Kotáskovy práce o celoživotním vzdělávání a vzdělávání dospělých dosáhly mezinárodního uznání a ohlasu. Později se staly jedním z podkladů pro tvorbu zásadní publikace UNESCO Learning to be, pod redakcí J. Faureho vydané v roce 1972. Paradoxně Kotáskovy srovnávací studie Current problems of Teacher Education (1970) a Lidée déducation permanente dans la réforme actuelle des systémes éducatifs et de la formation des mâitres (1972), publikované a citované v zahraničí, nedostaly povolení $\mathrm{k}$ publikaci $\mathrm{v}$ češtině v době, kdy již fungovaly normalizační mechanismy.

Druhá polovina 60. let s uvolňující se společenskou atmosférou, vrcholící Pražským jarem v roce 1968, otevřela Jiřímu Kotáskovi dvě další velké př́íležitosti, kterých využil s důkladností sobě vlastní. Významnou kapitolou odborného života Jiř́ho Kotáska je jeho vědecko-organizační a koncepční činnost v Pedagogické společnosti. Československá pedagogická společnost (ČSPS) byla založena v roce 1964 jako akademické sdružení výzkumných pracovníků, publikujících vysokoškolských pedagogů a školských odborníků. Jiří Kotásek se stal jejím vědeckým tajemníkem. Podílel se na koncipování profilu společnosti, formulaci statutu a programu její vědecké činnosti. Pedagogická společnost v dané době výrazně ovlivňovala vědeckou metodologii a za- 
měření české pedagogiky. Působila na decentralizované bázi s aktivními pobočkami v celé republice. ČSPS zdůraznila již ve svém počátku význam vzdělávání jako mocného nástroje sociální změny, důležitost vědecké báze pro politické rozhodování o vzdělávání a nezbytnost svobody vědeckého bádání $v$ pedagogice, odmítla ideologicky dogmatickou pedagogiku. V dalších letech (1965-1967) provedla ČSPS kritickou analýzu poválečného vývoje československého vzdělávání na základě komparace s vývojem mezinárodním, soustředila se na fundamentální teoretické a metodologické problémy pedagogiky, otevřela cestu Komenského Všeobecné poradě na mezinárodní scénu. Ve všech těchto aktivitách se Jiř́ Kotásek výrazně angažoval a uplatnil svoji vědeckou erudici. V prosinci 1968, již v posrpnové atmosféře, kdy byla Společnost rozdělena v důsledku federalizace na českou a slovenskou část, byl Jiř́i Kotásek zvolen předsedou České pedagogické společnosti. $\mathrm{V}$ programovém referátu položil dưraz na vzdělávací politiku, mezinárodní spolupráci a kontakty s učitelskou veřejností.

Druhá výrazná oblast vědecké činnosti Jiř́ho Kotáska ve druhé polovině 60. let je spojena s interdisciplinární spoluprací s dalšími sociálními vědami. Tehdy se, pod vlivem futurologických sociálně-vědných studií západních a prognostických studií sovětských, formuje v Československu interdisciplinární tým při Filosofickém ústavu Československé akademie věd, vedený Radovanem Richtou. Jeho cílem bylo studium společenských a lidských souvislostí vědeckotechnické revoluce. Mezinárodní konference v dubnu 1968 a následně zpracovaná publikace Civilizace na rozcestí (Richta a kol. 1969) měla jako ústřední téma humanistický koncept civilizace a zdůraznila roli vzdělávání v sociálním a personálním rozvoji. Identifikace determinujících faktorů sociální změny představovala odlišný koncept od předchozího dogmatického pohledu na třídní boj a sociální revoluce, korespondovala s tehdejšími sociálními teoriemi ve světě a byla významným impulzem pro pedagogiku. Jiří Kotásek, spolu s dalšími českými pedagogy, K. Škodou, V. Pařízkem, H. Mukařovskou a M. Havlínovou, uplatnil v interdisciplinárním týmu zejména koncept celoživotního vzdělávání. Vychází z kritické analýzy tehdejšího školství a argumentuje pro široké všeobecné vzdělávání stř̌edoškolské úrovně, pro individualizaci učení žáků s dưrazem na procesy učení lidí ve všech životních situacích a rozpracovává koncepci využívání technických prostředků ve výuce. Myšlenky studie již před čtyřiceti lety anticipovaly pozdější teorie společnosti vědění. Zatímco překlad do angličtiny vyvolal zahraniční ohlasy, v domácím prostředí byly $\mathrm{v}$ období normalizace výsledky studie kritizovány a její další využití potlačováno pro údajnou ideologickou nevhodnost, protože inklinovala $\mathrm{k}$ teorii konvergence, nereflektovala tř́́dní rozdělení světa a nezohledňovala přednosti socialismu před kapitalismem.

V napjaté posrpnové atmosfére publikuje Jiří Kotásek kritické stanovisko ke vstupu vojsk Varšavské smlouvy a hájí nezávislost vědeckého bádání. V důsledku svých postojů, mezinárodních aktivit a publikační činnosti byl v období normalizace zařazen do centrální evidence politicky nespolehlivých osob. Je mu zakázána pedagogická, publikační a jiná veřejná činnost, včetně výjezdů na Západ. Zastaveno je ř́zení ke jmenování profesorem. Jiří Kotásek nesl velmi těžce vzdálení od života pedagogické komunity a možnosti ovlivňovat budoucí učitele ve své pedagogické činnosti. Po první vlně ideových a existenčních represí se, zejména díky podpoře tehdejšího prorektora 
UK, profesora Kraemera, může podílet na práci týmů zabývajících se informačním systémem pro školství a pedagogiku, koncepcí vzdělávání učitelů i metodologickými otázkami pedagogiky a oborových didaktik. Nesmí však publikovat. Některé jeho práce a kritická stanoviska jsou publikovány jako anonymní samizdaty či vydávány pod jmény jiných autorů, zejména $\mathrm{v}$ Ústavu školských informací a ve Výzkumném ústavu odborného školství. I když vyřazení z vědeckého života pro Jiř́ho Kotáska, téměř již dosahujícího na vrchol profesionální kariéry, znamenalo hluboké zklamání, pracoval dále i v podmínkách, $\mathrm{v}$ jakých by slabá osobnost nejspíše rezignovala.

$\mathrm{V}$ 80. letech, kdy došlo $\mathrm{k}$ jistému uvolnění striktních normalizačních pravidel, byl Jiř́ Kotásek přijat jako vědecký pracovník do Ústavu rozvoje vysokých škol. Tato nově se konstituující resortní instituce mu umožnila koncepční vědeckou práci. Zde se věnuje vysokoškolské pedagogice, studiu vysokoškolských systémů a metodologii jejich výzkumů. Publikuje již pod svým jménem expertní studie a studijní texty. Projektuje a organizuje pedagogické kurzy pro začínající vysokoškolské asistenty, podílí se na návrzích více- stupňového vysokoškolského studia a kvalifikací. Stále však nemá povoleny zahraniční cesty na Západ, avšak díky administrativnímu nedopatření vycestuje do Velké Británie na univerzitu v Surrey a účastní se kurzu lektorů pro tzv. staff development. Následně je vyzván, aby se podílel na koncepci vzdělávání vysokoškolských učitelů, což mu přineslo jisté zadostiučinění a možnost uplatnit svoji orientaci v teoriích a výzkumech vysokého školství, které v koncepčním dokumentu využil. Až do roku 1989 vedl oddělení vysokoškolské didaktiky v ÚVRVŠ, které pořádalo řadu celostátních a mezinárodních konferencí, jejichž ústřední osobností byl Jiří Kotásek. V roce 1985 byl vyslán dokonce na Kubu na přednáškový pobyt zaměřený na zkvalitňování vysokoškolské výuky. Díky jeho působení a důslednosti byla vytvořena v Československu sít vysokoškolských pracovišt', která zajištovala pedagogicko-psychologické vzdělávání učitelů vysokých škol. Koncem 80. let Jiří Kotásek iniciuje a rozvíjí zejména spolupráci se slovenskými partnery na vysokých školách a s Ústavem rozvoje vysokých škol v Bratislavě. Návrh vícestupňového vysokoškolského studia, na němž se Jiří Kotásek významně podílel, byl předložen koncem 80 . let rektorům vysokých škol. Nesetkal se tehdy s pochopením, předešel však svoji dobu a později další vývoj vysokých škol potvrdil jeho progresivnost.

Po listopadu 1989 je Jiří Kotásek rehabilitován, jmenován profesorem a vrací se na Univerzitu Karlovu. V lednu 1990 jej akademická obec zvolila děkanem Pedagogické fakulty UK. Tuto funkci chápal profesor Kotásek jako závazek k fakultě, kterou považoval za hlavní instituci univerzitního vzdělávání učitelů, vyžadující zásadní rekonstrukci po období normalizace, v němž se zkompromitovala ideologicky, pedagogicky i vědecky. V nové koncepci fakulty se vrací k idejím z roku 1946, ale usiluje o vytvoření moderní vysoké školy evropského typu. V první fázi působení ve funkci děkana, kromě řešení personálních a organizačních problémů, obnovuje spolu s týmem vedení fakulty její pedagogickou a vědeckou činnost. Je zásluhou Jiřího Kotáska, že po zrušení Pedagogického ústavu J.A. Komenského ČSAV se vytváří podmínky pro budování nového badatelského pracoviště na fakultě a redakce časopisu Pedagogika přechází také na fakultu. Dík jeho podpoře vzniká Ústav pedagogických a psychologických výzkumů (ÚPPV), do něhož povolává odborníky z dřívějšího akademického pracoviště a dal- 
ších institucí. Podobně i do dalších pozic na fakultě přicházejí pod Kotáskovým vedením odborníci a pedagogové, kteří se podílejí na realizaci nové koncepce. Jiří Kotásek ve funkci děkana usiluje také o rozvoj Ústavu pro další vzdělávání pedagogických pracovníků jako pracoviště univerzitního. Další vývoj, přes řadu reorganizací, potvrdil nosnost Kotáskovy koncepce. Na Pedagogické fakultě UK v současnosti působí Ústav výzkumu a rozvoje vzdělávání jako vědeckovýzkumné pracoviště s výrazným podílem na doktorském studiu oboru pedagogika, Ústav profesního rozvoje pedagogických pracovníkü, Centrum školského managementu a Stredisko vzdělávací politiky. Základy této struktury byly vytvořeny v období, kdy byl děkanem Jiří Kotásek.

V 90. letech se stává centrem zájmu Jiř́ho Kotáska transformace českého vzdělávacího systému a perspektivní vzdělávací politika. Tuto problematiku chápe Jiří Kotásek komplexně ve vzájemných souvislostech, $\mathrm{v}$ kontextu mezinárodního vývoje a evropských integračních procesů se zřetelem $\mathrm{k}$ podmínkám domácím. Již v první fázi transformace vytvárí na fakultě odborný tým, s nímž formuluje ideová východiska jednoho z prvních projektů vzdělávací reformy Budoucnost vzdělávání a výchovy v obnovené demokratické společnosti a ve sjednocující se Evropè (1991). Mezinárodní spolupráci a srovnávací studium vzdělávání $\mathrm{v}$ zahraničí považuje Jiří Kotásek za podstatnou a př̀irozenou součást rozvoje vzdělávání a pedagogiky. Inicioval založení oddělení srovnávací pedagogiky v ÚPPV a zařazení srovnávací pedagogiky do studijních programů učitelství, v nichž sám vyučoval. Zasloužil se o to, že 8 . světový kongres srovnávací pedagogiky se uskutečnil v roce 1992 v Praze, jeho hlavním organizátorem byla Pedagogická fakulta UK. Místo konání a hlavní téma kongresu, Vzdělávání, demokracie a rozvoj, byly v daném kontextu podstatné. Kongres přispěl k obnovení komunikace $s$ pedagogy ve světě, ideově podpořil transformaci vzdělávání $\mathrm{v}$ postsocialistických zemích stř̌ední a východní Evropy. Jiří Kotásek přednesl na kongresu referát Vize rozvoje vzdělávání v postsocialistické ére, vycházející ze situace v Československu. Soustředil se na proces transformace vzdělávání v kontextu zásadních změn sociálních, politických a ekonomických struktur. Identifikoval vzniklá dilemata a nastínil vize rozvoje vzdělávání po kolapsu předchozího režimu. Novou situaci označil jako laboratoř sociální a vzdělávací reformy a zdůraznil význam srovnávací pedagogiky pro transformační proces. Po kongresu byl čtyři roky viceprezidentem Světové rady společností srovnávací pedagogiky.

V první polovině 90 . let, ač zatížen děkanskými povinnostmi, veřejnou činností ve prospěch vzdělávací reformy a mezinárodními aktivitami, publikoval řadu expertních studií a článků v zahraničí i doma, zabývajících se vysokoškolským vzděláváním, vzděláváním učitelů a obecnými problémy transformace vzdělávacích systémů na konci milénia. Participoval na tvorbě expertní studie Vysoké školství (1991), která byla východiskem pro evaluaci českého vysokého školství examinátory OECD, vedl projekt Evropská perspektiva českého školství (1994-1996), podílel se na projektu Rady Evropy zaměřeném na vzdělávací reformy (1995) a na př́ípravě významného dokumentu OECD Zprávy o národní politice ve vzdělávání: Česká republika (1996).

Na práce v oblasti vzdělávací politiky navázal po dvou děkanských obdobích a studijním pobytu v USA na Stanfordské univerzitě, kde získal Fullbrightovo stipendium. Stal se vědeckým pracovníkem Střediska vzdělávací politiky, reprezentoval Českou re- 
publiku v řadě mezinárodních organizací. Významná byla zejména jeho činnost člena České komise UNESCO a delegáta ČR v Ř́dící radě Centra pro výzkum a inovace ve vzdělávání OECD (CERI) či delegáta ČR v Evropské síti pro politiku vzdělávání učitelů při Evropské komisi. Inicioval překlad významné Delorsovy zprávy Učení je skryté bohatství (UNESCO 1995) do češtiny, k němuž napsal úvod. Zprávu považuje za světovou chartu vzdělávání pro 21 . století. Spatřuje v ní globální východiska vzdělávací politiky, kterou v následujících letech obhajoval a prosazoval její principy v národních dokumentech, na jejichž zpracování se významně podílel.

V roce 1996 přijal Jiří Kotásek funkci poradce ministra školství, v níž působil po celá další léta. Uplatňoval v ní nejen svou vysokou expertnost, ale také značnou dávku strategie a diplomatického jednání a smysl pro praktické uplatnění teoretického fundamentu vzdělávací politiky, $\mathrm{k}$ jehož zvědečtění významně přispěl. $\mathrm{V}$ roce 1999 byl Jiří Kotásek pověren vedením týmu, který zpracoval stěžejní dokument české vzdělávací politiky Národní program rozvoje vzdělávání v České republice. Této práci, kterou později označil za jeden $\mathrm{z}$ nejobtížnějších, ale i nejzajímavějších úkolů, který v životě řešil, věnoval podstatnou část své odborné kapacity. Metodologická východiska Bílé knihy chápal jako specifický druh vědeckého poznání, proces její tvorby za náročné kolektivní dílo, v němž dialog mezi odbornou a učitelskou veřejnost je podstatný. Zázemí pro tvorbu Bílé knihy a náročné procedury spojené s její př́pravou vytvořil Ústav výzkumu a rozvoje školství Pedagogické fakulty UK, jehož pracovníkem od roku 1998 až do konce svého života Jiří Kotásek byl. Tvorba Bílé knihy se stala součástí výzkumných a vývojových prací ústavu, odborná stanoviska jeho pracovníků a pracovníků fakulty ovlivnila dokument. Když vzpomínám na toto období, vybaví se mi řada situací, v nichž Jiří Kotásek neúnavně posunoval práci dopředu, inicioval autorské semináře a diskuse, pro něž jsme připravovali výchozí texty, formulovali klíčové otázky, byli moderátory či zpracovateli závěrů. Při svém plném nasazení a angažovanosti spoléhal na spolupráci a vyvolával entuziasmus celého týmu. Proces př́pravy dokumentu byl popsán ve výroční zprávě MŠMT ČR za rok 2000.

Po prrijetí dokumentu vládou ČR v roce 2001 se Jiří Kotásek obrátil k širší pedagogické veřejnosti. Na sjezdu České pedagogické společnosti v roce 2002 přednesl referát, $\mathrm{v}$ němž zdůvodnil metodologická východiska a smysl dokumentu z odborných pozic. Dostalo se mu pozitivní zpětné vazby, což ho velmi těšilo, a přijetí dokumentu veřejností považoval za vrcholné zadostiučinění a zhodnocení výsledků práce odborníkủ. Jako poradce ministryně obhajoval Jiří Kotásek koncepci, principy a strategické linie Bílé knihy i v dalších letech. Zejména při tvorbě návrhu školského zákona mu záleželo na tom, aby nebyl vytvořen jen formální dokument, ale aby byl pochopen a kodifikován smysl a cíl změn a vyjádřeny potřeby vzdělávání $\mathrm{v}$ demokratickém státu. Jeho návrh, aby byly tyto myšlenky vtěleny do preambule zákona, nebyl přijat, protože podle názoru právníků to neodpovídá formě a dikci české legislativy, což ho oprávněně mrzelo. $\mathrm{O}$ to více se snažil interpretovat smysl a cíle vzdělávání $\mathrm{v}$ řadě referátů a statí publikovaných doma i v zahraničí, vystupoval veřejně i v médiích.

V letech 1999-2004 byl Jiří Kotásek spoluřešitelem výzkumného záměru Rozvoj národní vzdělanosti a vzdělávání učitelů v evropském kontextu. Výstupy jeho výzkumu byly publikovány v několika sbornících a shrnuty ve dvou kapitolách monografie Úlo- 
ha školy v rozvoji vzdělanosti (Walterová a kol. 2004). V nich se Jiř́ Kotásek zabýval jednak transformací školy a charakteristikami základních linií vzdělávací politiky, jednak budoucností školy a vzdělávání. $V$ posledních letech se soustředoval právě na problémy pedagogické futurologie. Aplikoval metodologii scénářů budoucnosti, s níž se seznámil prostřednictvím své účasti na projektu OECD-CERI, a provedl pozoruhodný výzkum v českém prostředí. Jeho výsledky potvrdily uznávání významu školy jako nezastupitelné sociální instituce a organizace zaměřené na procesy učení. Podpořily i budoucí koncentraci našeho pracoviště na výzkum školního vzdělávání.

Jiří Kotásek byl jedním z hlavních iniciátorů a spoluautorů projektu Centra základního výzkumu školního vzdělávání. Dočkal se zprávy o tom, že projekt byl přijat a získal finanční podporu MŠMT ČR. Zprávu o přijetí projektu uvítal s upřímnou radostí a zadostiučiněním ne pro sebe osobně, ale pro pedagogiku, která si zaslouží konečně mít, podle jeho slov, odpovídající pracoviště a podmínky pro základní výzkum.

Poslední referát, který přednesl na Kulatém stolu vzdělávací politiky Bílá kniha po pèti letech 23. února 2006, bilancoval kriticky, s obdivuhodnou důkladností a analýzou klíčových problémů vývoj školské politiky v České republice (referát byl publikován v Učitelských listech, č. 2, říjen 2006).

Nelze alespoň nezmínit pedagogickou činnost Jiř́ho Kotáska a jeho úzký vztah ke vzdělávání učitelů. Zásadně obhajoval univerzitní magisterské studium pro učitele všech stupňů školy a vyvážený rozsah odborné, pedagogicko-psychologické, didaktické a praktické prrípravy ve studijních programech. Podporoval vznik zákona o pedagogických pracovnících a podařilo se mu obhájit výše zmíněné požadavky. V pedagogické činnosti se věnoval Jiří Kotásek v posledních letech zejména vedení doktorandů, vedl kurzy srovnávací pedagogiky a vzdělávací politiky. Vyškolil řadu doktorandů, kteří v současnosti působí na významných pozicích na vysokých školách, výzkumných institucích a ve významných národních i mezinárodních organizacích. Ovlivnil desítky ředitelů škol a pracovníků školské správy, kterým přednášel ve studiu školského managementu. Vzpomínat na něho budou učitelé, pro něž přednášel obzvláště rád a jejichž vzdělávání a profesi věnoval značnou část svých výzkumů a odborných publikací. Jeho přednášky se vyznačovaly vždy jasnou, promyšlenou strukturou a precizním jazykem, vědeckou argumentací, doprovázením příklady i osobními zkušenostmi, což oceňovali studenti i kolegové. Jako předseda habilitačních komisí podpořil akademickou graduaci nové generace odborníků. Jako členu vědeckých rad a Asociace děkanů pedagogických fakult se mu podařilo prosadit mnohé progresivní změny, posilující prestiž pedagogických fakult.

Dílo Jiř́ho Kotáska se vyznačuje pozoruhodnou šiŕí záběru, kontinuitou a soustředěním na podstatné oblasti oboru. Jeho komparace vzdělávacích soustav a analýzy vzdělávacích reforem jsou stěžejním přínosem pro srovnávací pedagogiku, oceňovaným i v zahraničí, a východiskem pro další oblasti pedagogiky, v níž se angažoval. Komparace a cit pro reálné problémy vzdělávacího systému jej přivedly $\mathrm{k}$ problémům vzdělávací politiky, na budování jejíž vědeckých základů se podílel zásadně. Jako jeden z prvních českých pedagogů rozpracoval koncept celoživotního vzdělávání a aplikoval jej na vzdělávání učitelů. Založil vzdělávání vysokoškolských učitelů, přispěl k rozvoji vysokoškolské didaktiky a teorie vysokého školství. Zasloužil se o rozvoj obecné di- 
daktiky jako teorie výuky založené na interakci vyučovací činnosti učitelů a učební činnosti žáků se širokým zázemím v kontextu působení vnějších a vnitřních faktorů na charakter této interakce. Jeho argumentace ve prospěch oborových didaktik přispěla $\mathrm{k}$ posílení jejich vědeckého statusu. $\mathrm{V}$ neposlední řadě je třeba uvést jeho př́inos ke koncepci profesního vzdělávání učitelů a argumentovaného potvrzení jeho univerzitace.

Vnitřní kontinuita $\mathrm{v}$ díle Jiř́ho Kotáska byla hluboce zakotvena $\mathrm{v}$ kořenech a tradicích české pedagogiky a jejich vazbách na evropské hodnoty. Tato vnitřní integrita jeho díla byla zásadním prínosem $\mathrm{k}$ revitalizaci české pedagogiky a rekonstrukci českého školství v procesu reintegrace do Evropy po roce 1989. Jiř́ Kotásek, při veškerých zásluhách odborných, byl velmi bohatá a harmonická osobnost, vyzařující energii a životní optimismus, které uměl přenášet na ostatní, stejně tak jako lidskou poctivost, solidnost a opravdovost. Jeho radost $\mathrm{z}$ úspěchu ostatních byla naprosto upřímná, rád se dělil o své zkušenosti, nezištně dával k dispozici materiály a publikace, které získal na zahraničních cestách, neustále přicházel s novými inspiracemi. Byl vědec značné erudice, velmi pracovitý, nikdy však nebyl zahleděný jen do své vlastní práce. Dával přednost dialogu týmové práci, oceňoval její vnitřní soudržnost a přijímal ochotně různé role v týmu. Jako koordinátor i partner či spoluřešitel pracoval vždy s vysokou úrovní profesionality a požadavky na kvalitu. Přitom byl gentleman a vynikající společník s úžasným smyslem pro humor.

Milý Jiř́, Tvoje fyzická přítomnost nám moc chybí, ale jinak jsi stále mezi námi. Odkaz Tvého díla se neuzavřel, je otevřený pro pokračovatele, za něž se považujeme, a chceme mu dostát. 